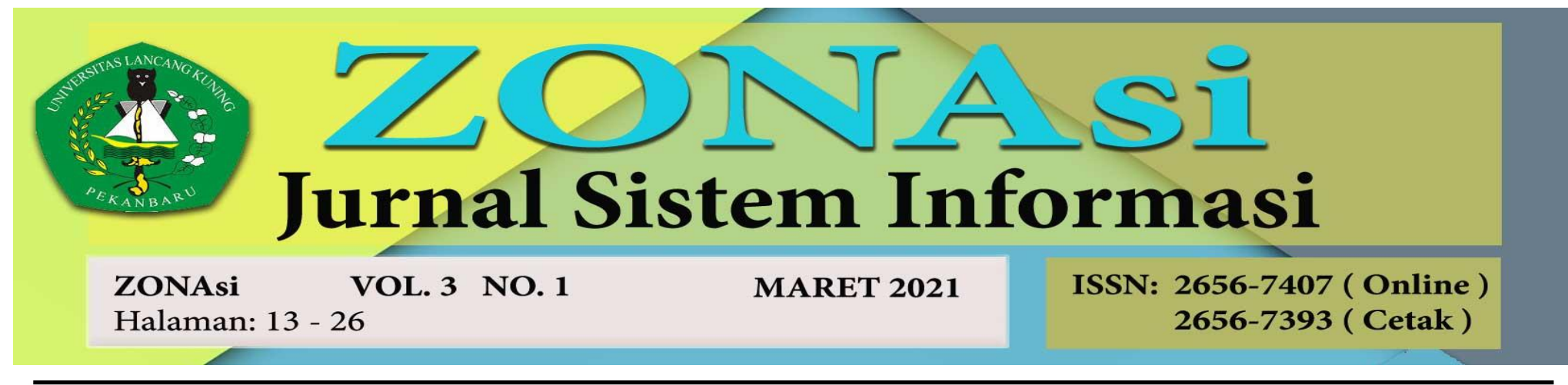

\title{
PERANCANGAN SISTEM INFORMASI PEMESANAN GAS LPJ BERBASIS ONLINE PADA PANGKALAN TETI TANJUNG MUTIARA KAB. AGAM
}

\author{
Arman $^{1}$, Elizamiharti ${ }^{2}$, Nelfira $^{3}$, Fauziah Yovi Yanti ${ }^{4}$ \\ 1,2,3,4 Program Studi Sistem Informasi \\ STMIK Indonesia Padang \\ E-mail: ${ }^{1}$ arman@stmikindonesia.ac.id, ${ }^{2}$ elizamiharti@stmikindonesia.ac.id, \\ ${ }^{3}$ nelfira@stmikindonesia.ac.id, ${ }^{4}$ febri.liantoni@gmail.com
}

\begin{abstract}
This research is motivated by the high interest and demand for LPG gas among the people in Tanjung Muatiara resulting in LPG gas often experiencing scarcity at several gas bases, all because the people only make reservations at bases in their home environment. To get information about LPG gas supplies, the public must visit bases to directly inquire of LPG gas supplies to the base owner. For this reason, through this research a website-based online design and application of LPG gas ordering information system was conducted. The system design in this application program uses the PHP programming language and MySQL database. The software development model used in this study is the waterfall SDLC model often also called sequential linear nods or classic life cycles. This study aims to build an information system that can provide information about LPG gas inventories at Teti Tanjung Mutiara Base and implement a website as a medium to promote and place online orders at Teti Tanjung Mutiara so as to facilitate the ordering process by customers.
\end{abstract}

Keywords: System Information, Ordering, LPG, Online

\begin{abstract}
Abstrak
Penelitian ini dilatarbelakangi oleh tingginya minat dan permintaan gas elpiji di masyarakat Tanjung Muatiara yang mengakibatkan gas elpiji sering mengalami kelangkaan di beberapa pangkalan gas, semua karena masyarakat hanya melakukan reservasi di pangkalan-pangkalan di lingkungan rumahnya. Untuk mengetahui pasokan gas LPG, masyarakat harus mendatangi pangkalan untuk menanyakan langsung pasokan gas elpiji kepada pemilik pangkalan. Untuk itu, melalui penelitian ini dilakukan perancangan dan aplikasi sistem informasi pemesanan gas LPG online berbasis website. Perancangan sistem pada program aplikasi ini menggunakan bahasa pemrograman PHP dan database MySQL. Model pengembangan perangkat lunak yang digunakan dalam penelitian ini adalah model SDLC waterfall yang sering disebut juga sequential linear nods atau siklus hidup klasik. Penelitian ini bertujuan untuk membangun sistem informasi yang dapat memberikan informasi mengenai persediaan gas LPG di Pangkalan Teti Tanjung Mutiara dan mengimplementasikan website sebagai media untuk mempromosikan dan melakukan pemesanan secara online di Teti Tanjung Mutiara sehingga dapat memudahkan proses pemesanan oleh pelanggan.
\end{abstract}

Kata Kunci: Sistem, Informasi, Pemesanan, LPG, Online 


\section{PENDAHULUAN}

Sekarang ini perkembangan ilmu pengetahuan dan teknologi sudah berkembang secara cepat dan pesat (Ramadhani 2011), sekarang ini penggunaannya sudah merambah ke berbagai perusahaan atau instansi dan masarakat umum yang sudah menggunakan dan menmanfaatkan sarana teknologi (Arman1, Wahyudi2 2019), terlebih dalam penggunaan sistem informasi yang dapat meningkatkan efektivitas kerja yang pada intinya guna memaksimalkan pendapatan dalam segi usaha atau bisni (Anggadini 2013). Komputer merupakan sebuah alat elektronik yang dapat menyimpan, mengolah data, dan memberikan informasi yang dibutuhkan secara cepat dan akurat yang dapat menunjang bagi instansi, perusahaan dan manusia guna memaksimalkan kemudahan dalam menjalankan aktifitas sehari-hari (Kurniawan 2015).

Salah satu bidang usaha rumahan yang sudah menggunakan computer adalah pangkalan teti, dimana teknologi informasi digunakan untuk pemasaran gas LPG kepada pelanggannya yang ada di sekitar tanjung mutiara. Pangkalan Teti adalah sebuah perusahaan distributor gas yang menjual bermacam-macam jenis gas yang pemasarannya ditujukan kepada pelangan, masyarakat, rumah makan, rumah sakit, dan perusahaan industri. Dalam teknik pemesanan Pangkalan Teti yaitu dengan cara pelangan lasung ke pangkalan teti untuk membeli gas. Sejak tahun 2007 diperlakukannya konversi minyak tanah ke gas, mengakibatkan tingginya permintaan gas oleh pelanggan ke pangkalan. Hal ini disebabkan oleh manajemen distribusi dan penyampaian informasi yang belum optimal. Untuk melakukan transaksi pembelian gas LPG Pelanggan harus datang langsung untuk melakukan pembelian gas LPG. Hal tersebut tentu tidak efisien jarak yang jauh dan membutuhkan waktu yang lebih lama karena harus mengunjungi pangkalan-pangkalan gas LPG tersebut satu persatu. Padahal masih banyak pangkalan-pangkalan lain yang memiliki persediaan gas LPG yang tidak jauh dari lingkungan mereka.

Saat ini gas LPG (Liquified Petroleum Gas) $3 \mathrm{Kg}$ banyak digunakan oleh masyarakat, terutama untuk bahan bakar kompor gas. Kelebihan pemakaian gas LPG sebagai bahan bakar bila dibandingkan dengan bahan bakar lainnya misalnya kayu bakar ataupun minyak tanah yaitu mudah dalam penggunaan, lebih bersih, dan lebih murah karena disubsidi pemerintah. Berdasarkan hal tersebut menjadikan gas LPG semakin diminati oleh masyarakat baik itu ibu rumah tangga maupun untuk pemilik usaha. Untuk melakukan transaksi pembelian gas LPG Pelanggan harus datang langsung untuk melakukan pembelian gas LPG (Riswan and Sahari 2019). Hal tersebut tentu tidak efisien jarak yang jauh dan membutuhkan waktu yang lebih lama karena harus mengunjungi pangkalan-pangkalan gas LPG tersebut satu persatu, padahal masih banyak pangkalan-pangkalan lain yang memiliki persediaan gas LPG yang tidak jauh dari lingkungan mereka. Hal ini disebabkan karena masyakat belum menggunakan media pemesaan secara online dan harus datang langsung untuk melakukan pembelian gas LPG.

Tingginya minat dan permintaan akan gas LPG mengakibatkan gas LPG sering mengalami kelangkaan di beberapa pangkalan karena masyarakat hanya melakukan pemesanan pada pangkalan di lingkungan rumah mereka saja. Pada saat ini pelanggan kesulitan mendapatkan informasi persediaan gas LPG. Untuk mendapatkan informasi tentang persediaan gas LPG masyarakat harus mengunjungi pangkalan-pangkalan untuk langsung menanyakan persediaan gas LPG kepada pemilik pangkalan.

Berbeda dengan pangkalan-pangkalan lain pada umumnya yang sering kehabisan persediaan gas LPG, Pangkalan Teti Tanjung Mutiara yang merupakan salah satu pangkalan gas LPG terbesar di Kabupaten Agam sering terjadi penumpukkan persediaan gas LPG. Hal ini disebabkan karena masyarakat tidak mendapatkan informasi tentang persediaan gas LPG tersebut. Pangkalan Teti Tanjung Mutiara setiap bulan melakukan pemesanan gas LPG ratarata 1680 tabung dengan rincian 845 rumah tangga, 418 usaha mikro dan 417 usaha lainnya. 
Sedangkan rata-rata pelanggan yang melakukan pembelian gas LPG hanya sekitar 200 orang dalam sebulan.

Pada saat ini pengolahan transaksi penjualan dan pemesanan gas LPG pada Pangkalan Teti Tanjung Mutiara masih belum memiliki sistem penjualan dan pemesanan secara online dan masih menggunakan media telepon atau konsumen datang lansung untuk memesan gas LPG. Hal tersebut tidak efisien dan menyebabkan pemesanan gas LPG tidak mengalami peningkatan yang signifikan walaupun minat konsumen sangat tinggi. Selain itu perkembangan perusahaan agak lambat. Permasalahan lain yang dihadapi Pangkalan Teti Tanjung Mutiara adalah kesulitan dalam mempromosikan usahanya sehingga pangsa pasar relaitif kecil yang mengakibatkan kecilnya jumlah penjualan dan sedikitnya jumlah order permintaan gas LPG. Selain itu juga dalam hal pemasaran pangkalan teti ini, dengan tingginya permintaan masyarakat akan kebituhan gas tersebut menyebabkan gas sering menjadi langkah di berbagai pangkalan yang ada di tanjung mutiara tersebut, dan juga terjadinya antrian untuk pemesanannya. Semua itu disebabkan pemesanan gas LPG yang dilakukan oleh pelanggan masih secara konvesional, sangat menyulitkan masyarakat dalam melakukan pemesanan gas LPG karena harus datang langsung ke pangkalan-pangkalan terdekat. Sistem pemesanan gas LPG yang masih konvensional mengakibat masyarakat kesulitan mendapatkan informasi ketika gas LPG mengalami kelangkaan. (Nindya Prasasti, 2017).

Berdasarkan hal tersebut peneliti melakukan penelitian tentang penjualn gas secara online, Beberapa penelitian sebelumnya antara lain Penelitian pertama, (Wulansari1, Rahayu2, and Riza3 2019) dengan judul penelitiannya aplikasi pemesanan bahan bakar minyak memalui media whatsapp menggunakan algoritma whatsapp gateway ( studi kasus PT. Pertamina patra niaga. berdasarkan wawancara bersama narasumber 10 Januari 2019, menjelaskan bahwa kepala SPBU diperbolehkan melakukan pemesanan bahan bakar minyak melalui media whatsapp. Tetapi, kantor pusat sedikit kewalahan saat melakukan perekapan atau bahkan lupa untuk mencatatnya. Dengan terjadinya kesalahan tersebut, membuat perusahaan rugi besar. Maka dibutuhkan analisa dan aplikasi untuk membantu kantor pusat dalam merekap data permintaan. Dalam hal ini, Hasil dari penelitian ini yaitu aplikasi pemesanan bahan bakar minyak melalui media whatsapp. Aplikasi ini hanya digunakan oleh kantor pusat dan awak mobil tangki untuk validasi pengiriman bahan bakar minyak.

Kemudian peneliti kedua, (Suryadi 2012), dengan judul penelitian analisis dan perancangan sistem informasi pendistribusian gas LPG bersubsidi dengan metodologi object oriented studi kasus PT. XYZ. LPG merupakan gas hasil produksi dari kilang minyak atau kilang gas, yang komponen utamanya adalah gas propane $(\mathrm{C} 3 \mathrm{H} 8)$ dan butane $(\mathrm{C} 4 \mathrm{H} 10)$ yang dicairkan. Menimbang bahwa dalam rangka untuk menjamin penyediaan dan pengadaan bahan bakar di dalam negeri dan mengurangi subsidi Bahan Bakar Minyak (BBM) guna meringankan beban keuangan negara, perlu dilakukan substitusi penggunaan minyak tanah ke LPG maka keluar Peraturan Presiden Republik Indonesia Nomor 104 Tahun 2007 tentang penyediaan, pendistribusian, dan penetapan harga LPG. PT. XYZ menjadi salah satu Badan Usaha yang menyelenggarakan penyediaan dan pendistribusian LPG bersubsidi, hasil penelitiannya adalah untuk mengurangi kesalahan dan kecurangan pada saat distrubisi Gas maka dibutuhkan Sistem informasi, dengan sistem informasi proses pendistrubusian Gas akan lebih cepat dan akurat sehingga perusahaan dapat bekerja secara baik, efektif, dan efisien.

Penelitian berikutnya (Jayanti, Meilinda, and Desi 2018) dengan judul Perancangan Sistem Informasi Manajemen Distribusi Gas Elpiji Berbasis Web pada PT. Mita Kalbar Pontianak. Hasil penelitiannya, dengan adanya aplikasi ini diharapkan dapat digunakan untuk membangun sistem informasi sebagai media penyimpanan data distribusi dan laporan secara terkomputerisasi serta digunakan untuk membangun sistem informasi dalam upaya mengatur 
dan mengawasi penyaluran gas elpiji kepada konsumen. yang dilakukan Penelitian yang dilakukan.

Berdasrkan hasil dari beberapa peniliti diatas dapat disimpulkan bahwa aplikasi pemesanan gas berbasi online ini sangat membantu konsumen, penganlan dalam pemesanan gas, dan membutuhkan waktu yang relative, selan itu dengan adanya aplikasi ini dapat menghenat waktu dan biaya dalam pemesanannya.

Liquefied Petroleum Gas (LPG) PERTAMINA dengan brand ELPIJI, merupakan gas hasil produksi dari kilang minyak (kilang BBM) dan kilang gas, yang komponen utamanya adalah gas propana $(\mathrm{C} 3 \mathrm{H} 8)$ dan butana $(\mathrm{C} 4 \mathrm{H} 10)$ lebih kurang $99 \%$ (sembilan puluh sembilan persen) dan selebihnya adalah gas pentana (C5H12) yang dicairkan (Andrianal, Prasetyaningrum, and Kom 2019). Pangkalan teti merupakan salah satu distributor pendistribusian Gas LPG yang ada di tanjung mutiara Kab. agam. Atas dasar tersebut, maka untuk memperluas jaringan pemasaran dan meningkatkan daya saing, memberikan pelayanan dan solusi bagi para pelanggannya.

\section{METODE PENELITIAN}

Dalam penelitian ini peneliti menggunakan metode Web Engineering Method (Agus Umar Hamdani 2019) dan dan alat bantu perancangan menggunakan UML (Wira, Putra, and Andriani 2019). Metode penelitian merupakan cara ilmiah untuk mendapatkan data yang dibutuhkan dalam penelitian. Metode Web Enginerring Metode yang digunakan dalam penelitian adalah Web engineering yang merupakan rekayasa web yang mengadaptasi rekayasa perangkat lunak. Pengembangan sistem ini bertujuan menyusun sistem baru untuk menggantikan sistem lama secara keseluruhan atau memperbaiki sistem yang telah berjalan [10]. Metode web engineering terdapat 5 ( lima ) tahapan untuk dapat mengembangkan suatu perangkat lunak seperti Gambar. 1.

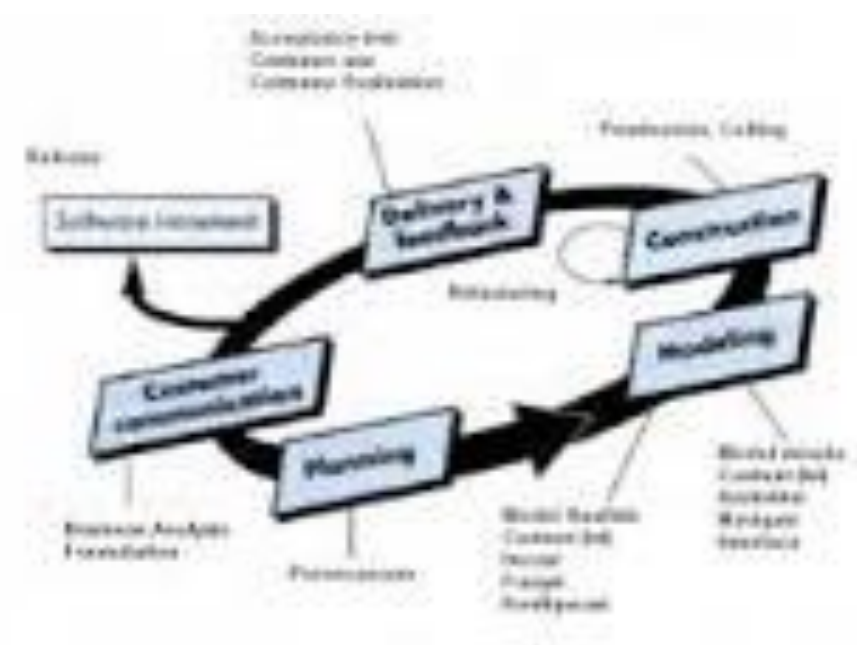

Gambar 1. Tahapan Web Engineering

Adapun tahapan dari web Enjineering tersebut antara lain (Marlinda and Hamid 2014) : 1. Customer communication. Komunikasi dalam hal ini terutama terkonsentrasi pada dua hal, analisa bisnis dan perumusan. Analisa bisnis akan mendefinisikan hal-hal apa saja yang akan termuat di dalam aplikasi web, misalnya pengguna web yang akan dirancang, perubahan potensial dalam lingkungan bisnis, integrasi antara web yang akan dibangun dengan situasi bisnis perusahaan, maupun database perusahaan. 
2. Planning, Perencanaan proyek pengembangan aplikasi web kemudian ditentukan, perencanaan akan terdiri dari pendefinisian pekerjaan dan target waktu atas pekerjaan maupun sub pekerjaan yang ditentukan tersebut.

3. Modeling, Tujuan dari aktivitas ini adalah untuk menjelaskan hal-hal apa saja yang memang diperlukan pada aplikasi yang akan dibangun dan solusi yang.

4. Construction, pembangunan aplikasi web yang memadukan antara perkembangan teknologi dengan tools pengembangan web yang telah ada.

5. Deployment, aplikasi web diciptakan untuk dapat berguna bagi kebutuhan pekerjaan, dapat dioperasikan oleh end-user, kemudian dilakukan evaluasi secara berkala, memberi saran kepada team pengembang, apabila diperlukan dilakukan modifikasi pada aplikasi web tersebut.

\section{HASIL DAN PEMBAHASAN}

Pada pengujian yang dilakukan dengan penerapan pemodelan UML terdapat beberapa langkah. Pemodelan UML yang dilakukan antara lain dengan membuat Use Case Diagram, Activity Diagram, Sequence Diagram dan Class Diagram.

\subsection{Use Case Diagram}

Use case diagram dapat digunakan selama proses analisa untuk menangkap requirements atau permintaan terhadap sistem pemesanan online dan untuk memahami bagaimana sistem tersebut harus bekerja. Adapun use case diagram sistem informasi pemesanan online pada Pangkalan Teti Tanjung Mutiara dapat digambarkan seperti sebagai berikut:

a. Use Case Diagram Login

Diagram menggambarkan proses login yang terjadi, baik itu Admin ataupun pimpinan. Adapun use case diagram login dapat dilihat pada Gambar 2.

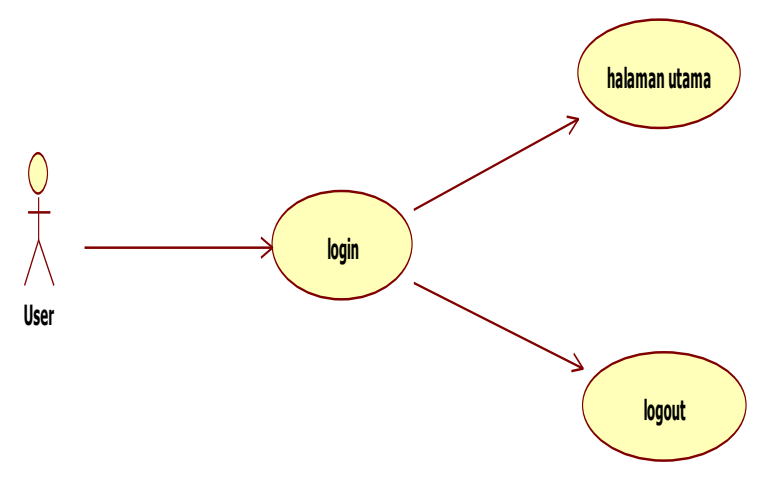

Gambar 2. Use Case Diagram Login

b. Use case Diagram Admin

Diagram ini menggambarkan aktivitas-aktivitas yang dapat dilakukan oleh Admin. Adapun use case diagram Admin dapat dilihat pada Gambar 3. 


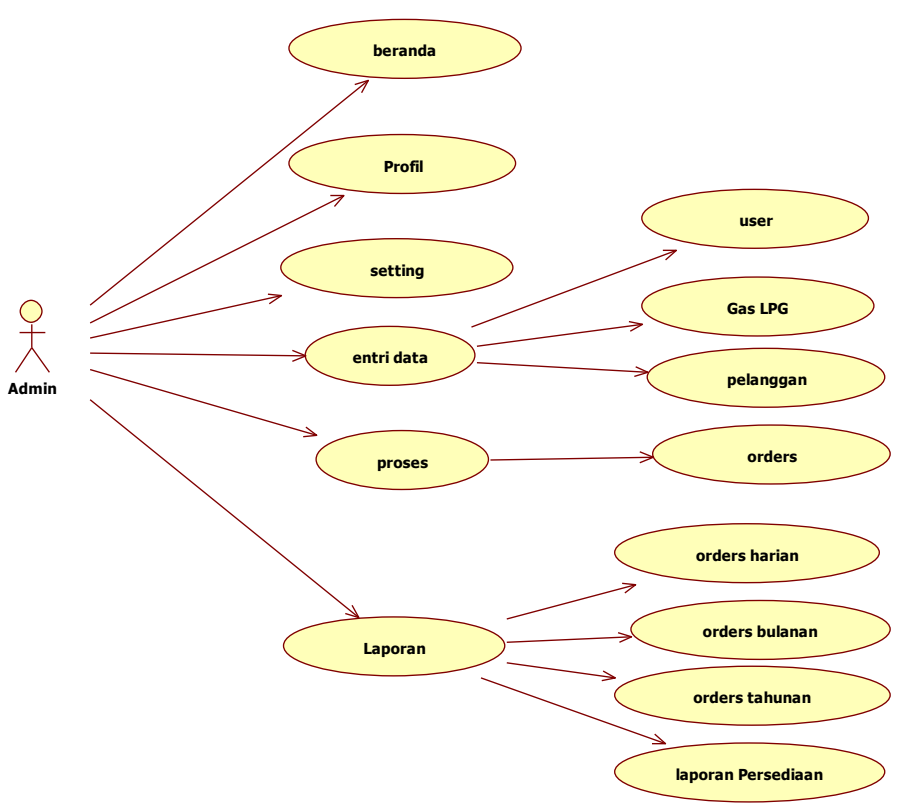

Gambar 3. Use Case Diagram Admin

c. Use Case Diagram Pimpinan

Diagram ini menggambarkan aktivitas-aktivitas yang dapat dilakukan oleh pimpinan. Adapun Use case Diagram Pimpinan dapat dilihat pada Gambar 4.

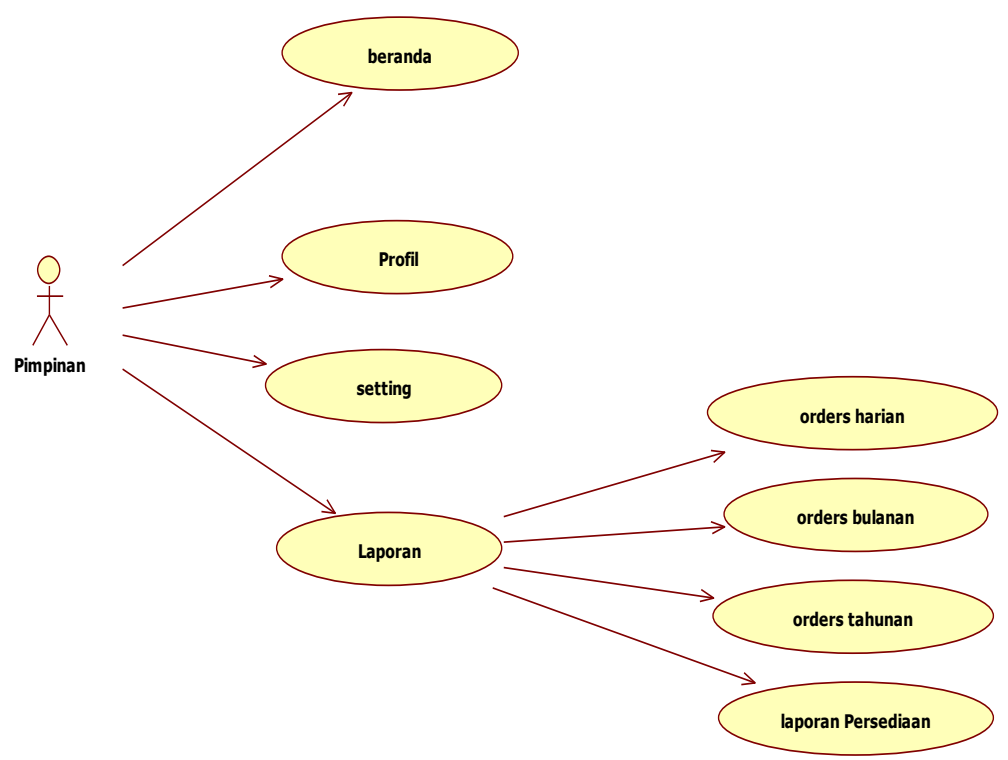

Gambar 4. Use Case Use case Diagram Pimpinan

d. Use Case Diagram Pelanggan

Diagram ini menggambarkan aktivitas-aktivitas yang dapat dilakukan oleh pelanggan dalam sistem informasi pemesanan gas LPG. Adapun Use case Diagram pelanggan dapat dilihat pada Gambar 5 


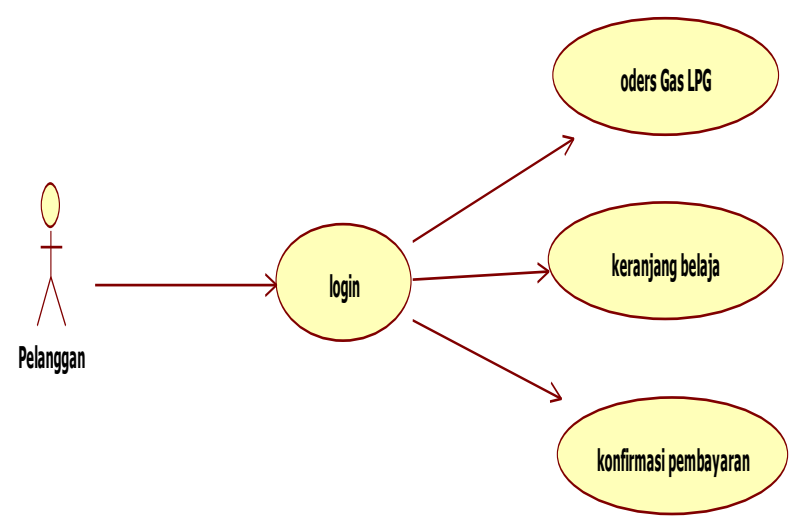

Gambar 5. Use Case Diagram Pelanggan

\subsection{Class Diagram}

Class diagram adalah sebuah spesifikasi yang jika diinstansiasi akan menghasilkan sebuah objek dan merupakan inti dari pengembangan dan rancangan berorientasi objek pada sistem informasi pemesanan online Pangkalan Teti Tanjung Mutiara. Class Diagram Pangkalan Teti Tanjung Mutiara.

\subsection{Activity Diagram}

Aktivitas menggambarkan proses yang berjalan, sementara use case sistem informasi pemesanan online menggambarkan bagaimana aktor menggunakan sistem untuk melakukan aktivitas. Adapun activity diagram sistem informasi pemesanan online Pangkalan Teti Tanjung Mutiara adalah sebagai berikut:

a. Activity Diagram Admin

Activity diagram Admin dapat dilihat pada Gambar 6.

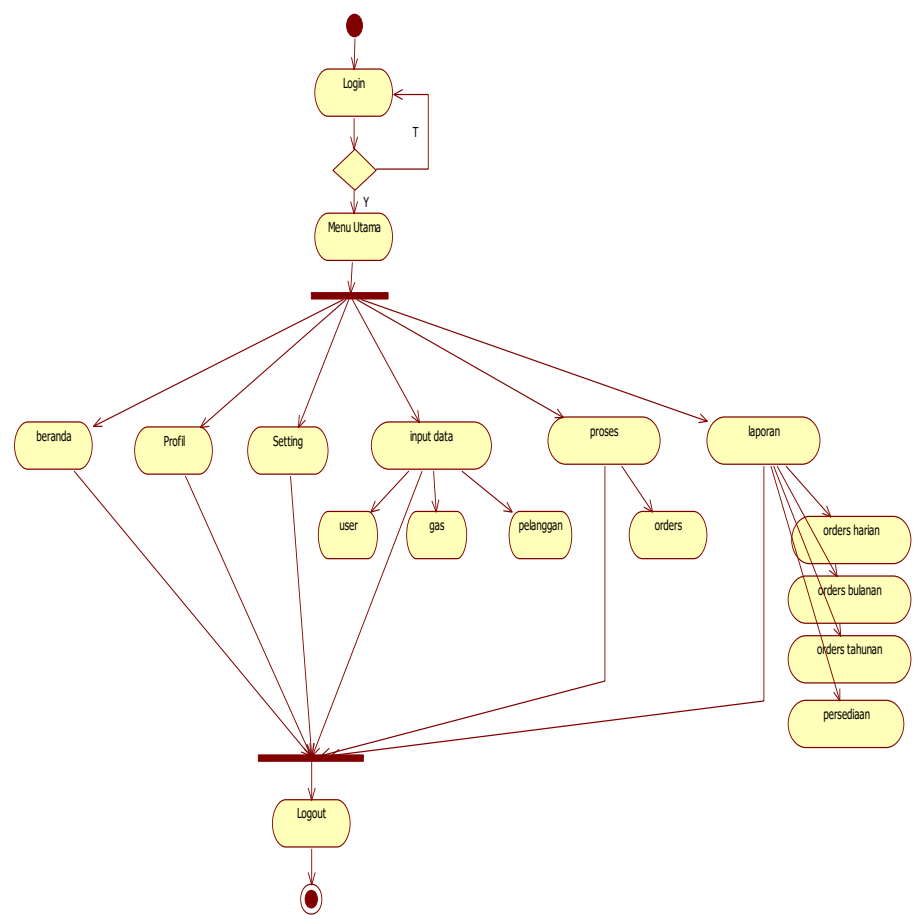

Gambar 6. Activity Diagram Admin 
b. Activity Diagram Pimpinan

Activity diagram pimpinan dapat dilihat pada Gambar 7

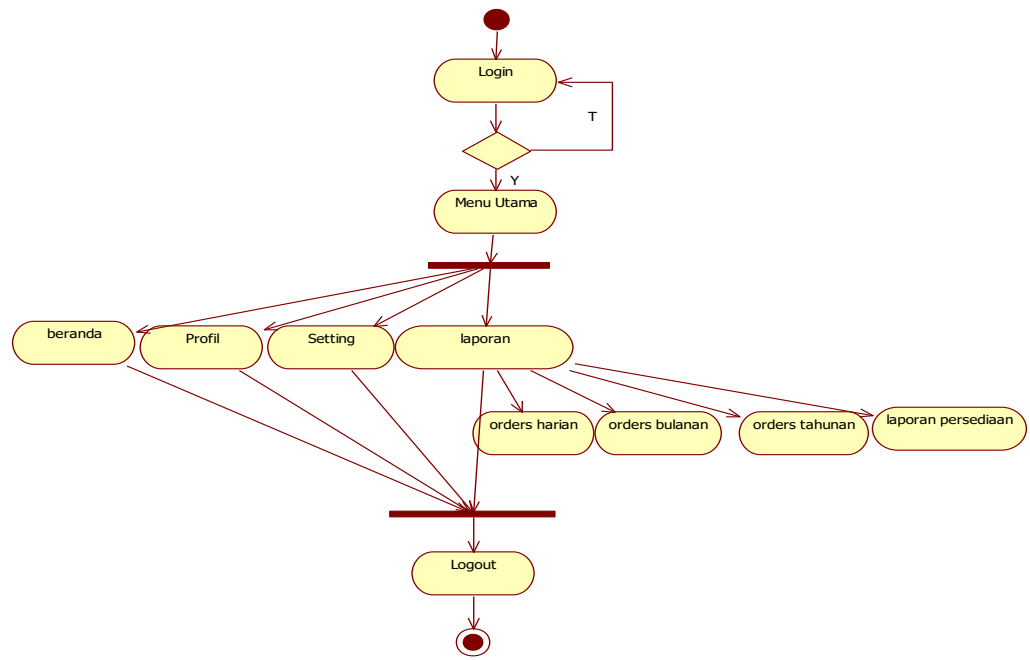

Gambar 7. Activity Diagram Pimpinan

c. Activity Diagram Pelanggan

Activity diagram pelanggan dapat dilihat pada Gambar 8

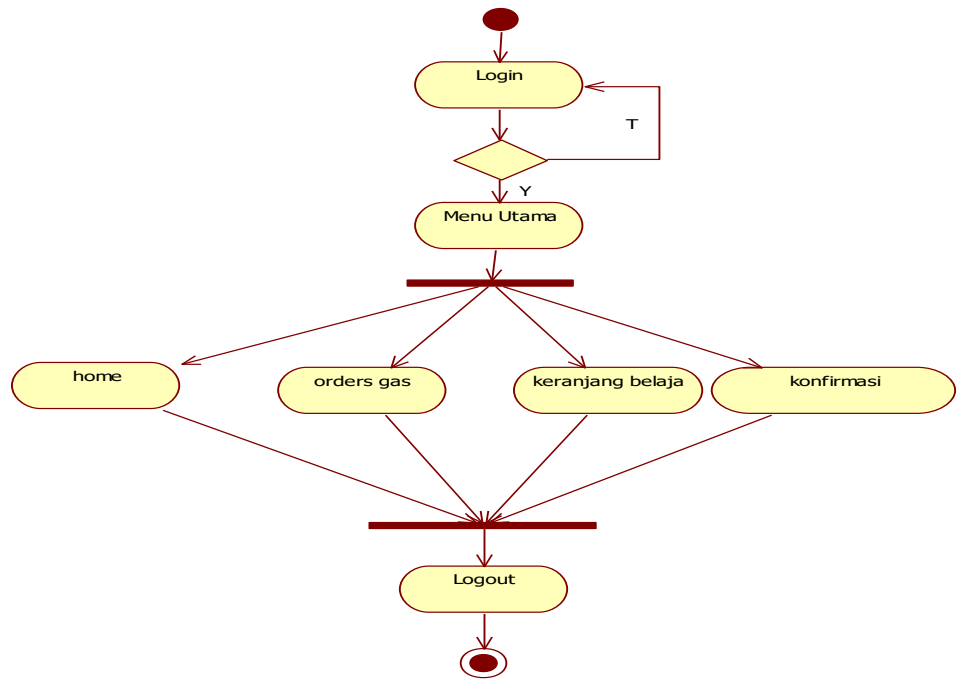

Gambar 8. Activity Diagram Pelanggan

\subsection{Implementasi Sistem}

Tahap implementasi pada sebuah sistem informasi merupakan tahap dimana sistem yang telah dirancang pada tahap sebelumnya diterapkan atau dioperasikan.

Berikut ini adalah pembahasan tentang implementasi yang telah dilakukan di Pangkalan Teti Tanjung Mutiara.

a. Halaman Utama Admin

Halaman utama adalah halaman yang pertama kali muncul saat pengguna berhasil masuk ke dalam sistem aplikasi. Pada halaman utama ini berisikan menu-menu yang dapat diakses oleh admin dapat dilihat pada Gambar 9. 


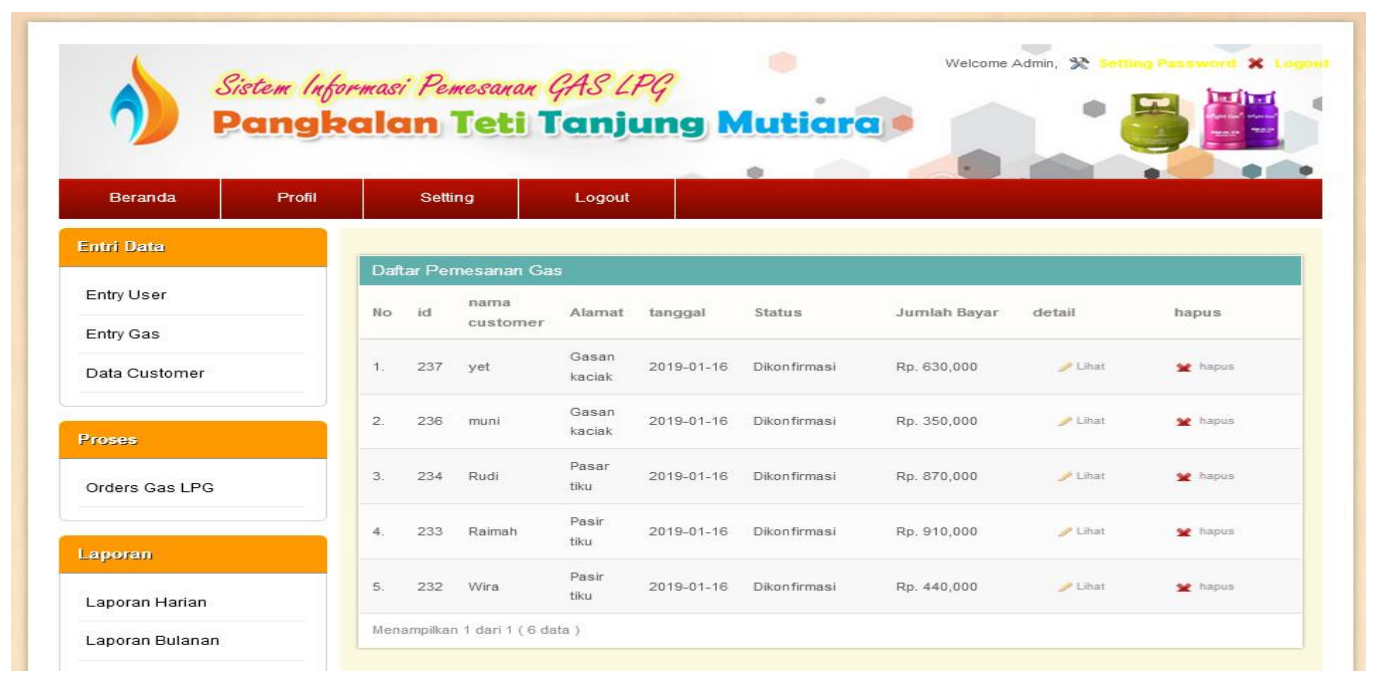

Gambar 9. Halaman Utama Admin

b. Halaman Login Pelanggan

Halaman login pelanggan merupakan halaman form yang digunakan oleh pelanggan untuk proses login yang akan memesan dan membeli gas ke pangkalan Teti Tanjung Mutiara.

c. Halaman Proses masuk keadmin

Halaman masuk admin ke aplikasi ini bertujuan agar admin dapat dalam masuk ke menu dan melihat aptivitas yang ada pada system. Untuk lebih jelasnya dapat dilihat pada Gambar 10.

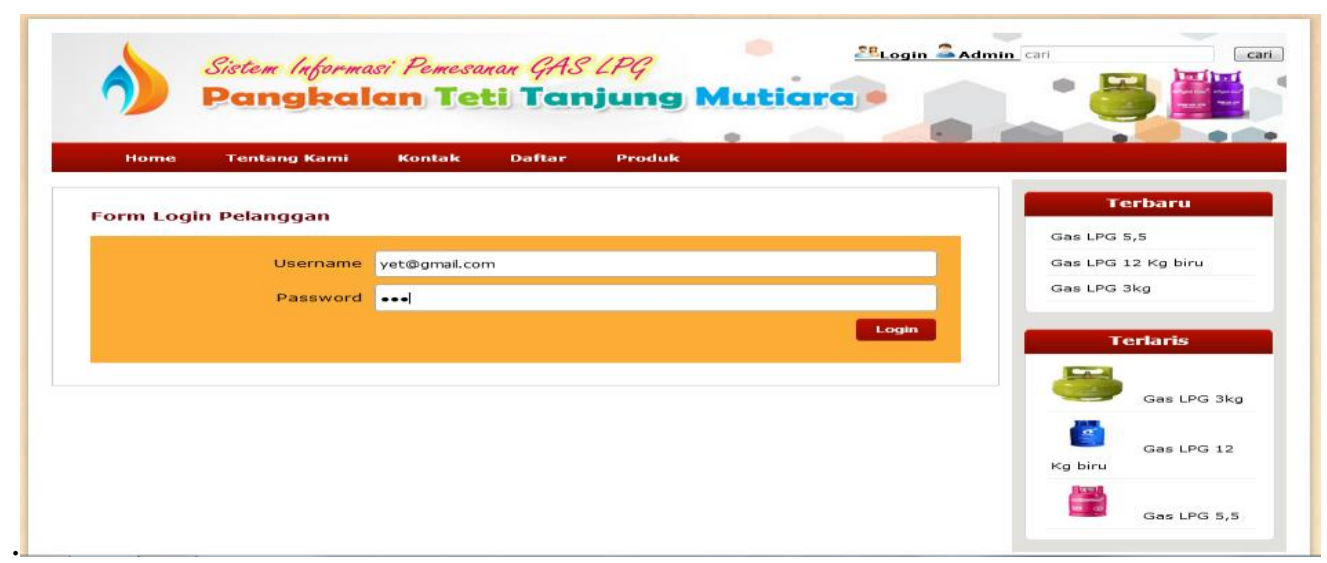

Gambar 10. Halaman login Admin

d. Halaman Utama Pelanggan

Halaman utama adalah halaman yang pertama kali muncul saat pengguna berhasil masuk ke dalam sistem aplikasi. Pada halaman utama ini berisikan menu-menu yang dapat diakses oleh pelanggan dapat dilihat pada Gambar 11. 


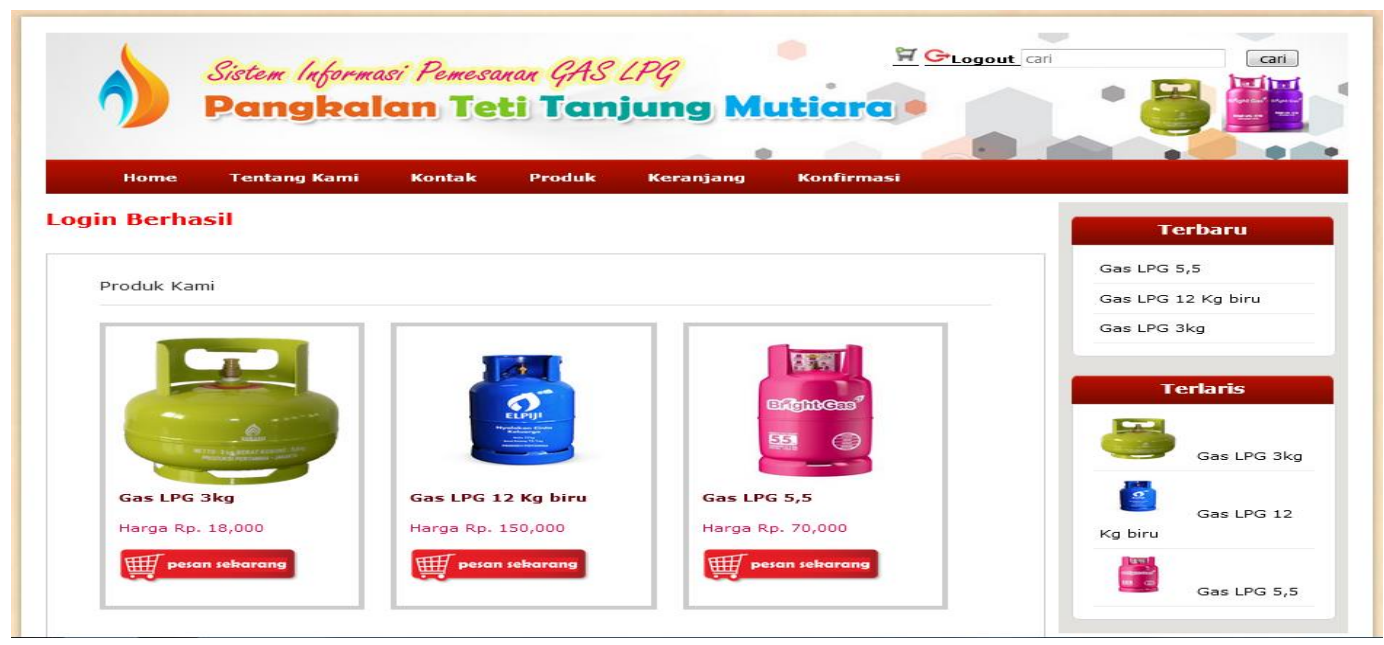

Gambar 11. Halaman Utama Pelanggan

e. Halaman Pendafataran

Halaman pendaftaran merupakan halaman yang digunakan oleh pelanggan untuk melakukan pendaftaran. Pada halaman pendaftaran pelanggan mengentrikan nama, email, username dan password dapat dilihat pada Gambar 12.

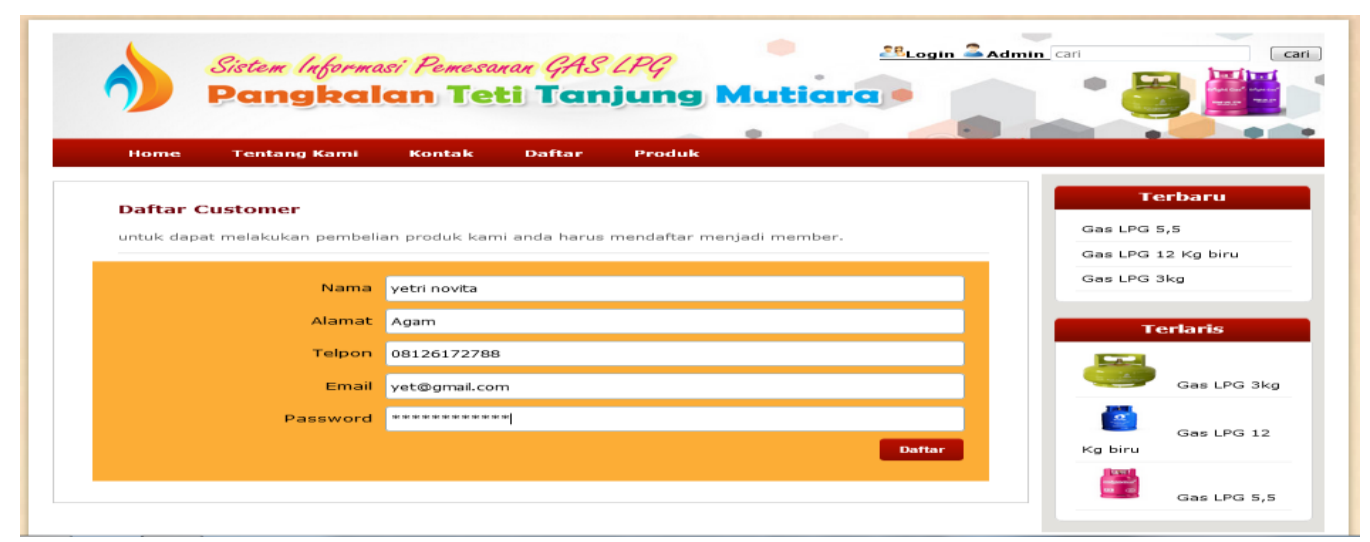

Gambar 12. Halaman Pendaftaran

f. Halaman Pemesanan Gas

Halaman pemesanan gas merupakan halaman yang digunakan oleh user untuk memesan gas. Adapun langkah dalam pemesanan gas adalah isi jumlah pesan, lalu simpan belanja dapat dilihat pada Gambar 13.

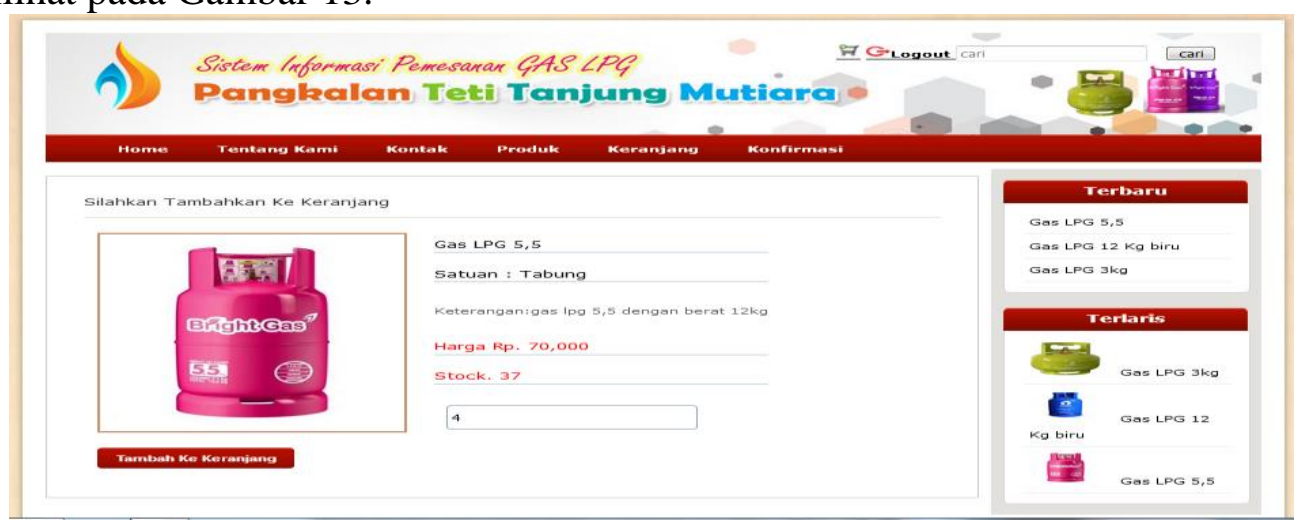

Gambar 13. Halaman Pemesanan Gas 
g. Halaman Keranjang Pemesanan

Halaman keranjang pemesanan merupakan halaman yang berisikan data tentang data pemesanan gas. Adapun halaman keranjang pemesanan dapat dilihat pada Gambar 14.

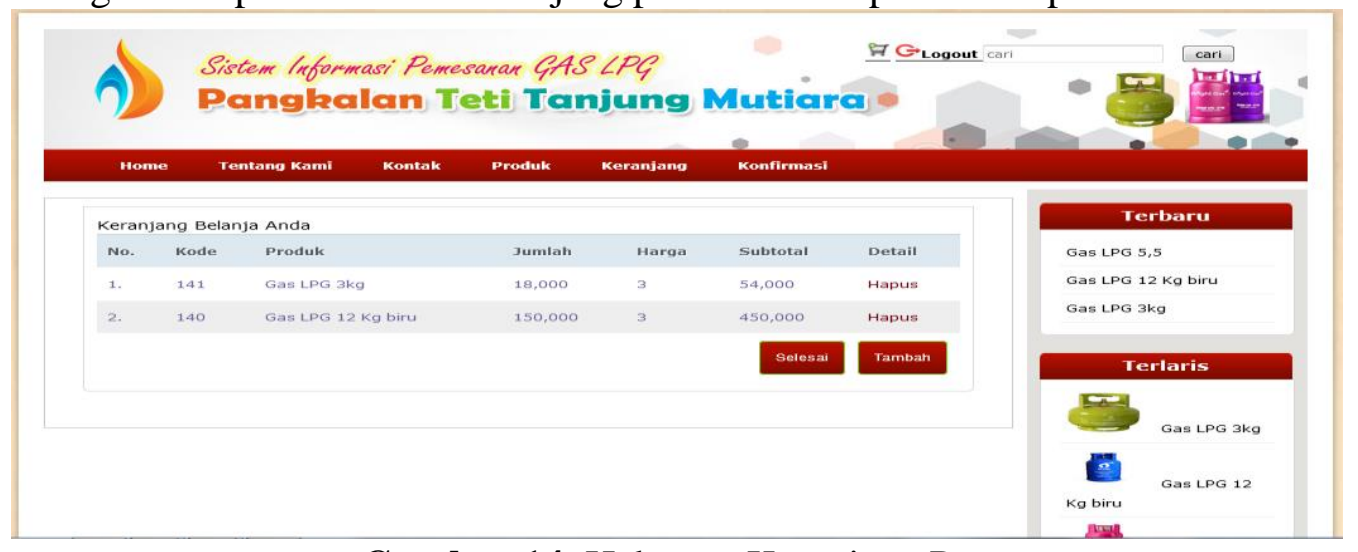

Gambar 14. Halaman Keranjang Pemesanan

h. Halaman Bukti Pemesanan

Laporan bukti pemesanan merupakan halaman yang berisikan data tentang data pemesanan gas. Adapun halaman bukti pemesanan dapat dilihat pada Gambar 15 .

\section{Pangkalan Teti Tanjung Mutiara}

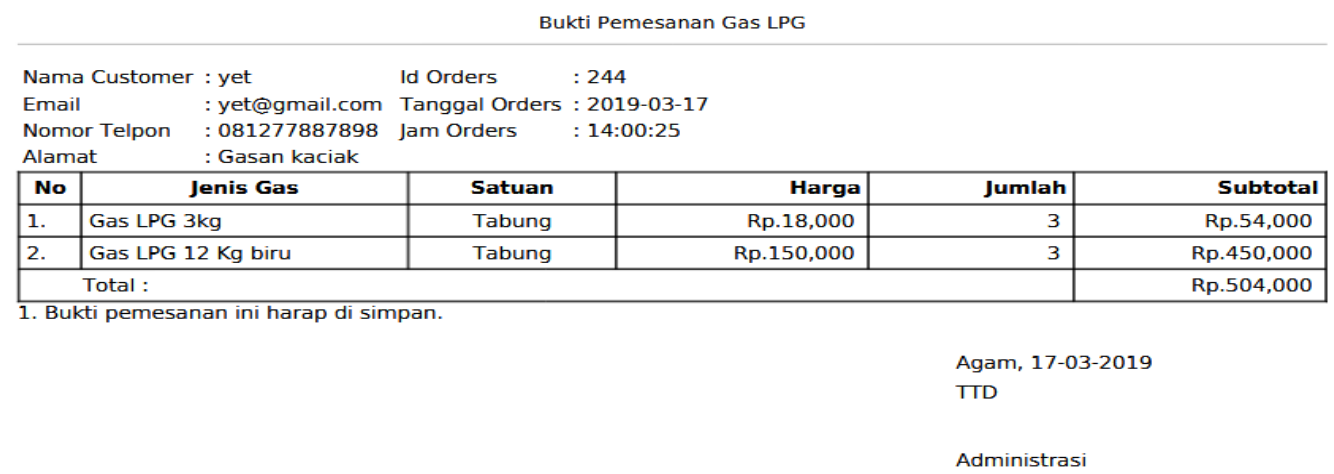

Gambar 15. Halaman Bukti Pemesanan

i. Halaman Laporan /Output

Halaman laporan ini merupakan laporan semua data yang ada pada system yang nantinya dapat dipergunakan untuk melihat semua kegiatan dalam system. Untuk lebih jelas dapat dilihat sebagai berikut :

1. Laporan Pelanggan Harian

Untuk dapat melihat laporan data pelanggan harian admin mengklik menu laporan data pelanggan harian. Kemudian admin akan diminta untuk mengklikan tahun dan nama pimpinan maka akan tampil laporan data pelanggan harian dapat dilihat pada Gambar 16. 


\section{ค) PANGKALAN TETI TANJUNG MUTIARA}

\begin{tabular}{|c|c|c|c|c|c|c|c|}
\hline \multicolumn{8}{|c|}{ LAPORAN PELANGGAN HARIAN } \\
\hline \multicolumn{8}{|c|}{ Tanggal:2019-01-16 } \\
\hline No & No Order & Pelanggan & Jenis Gas & Harga (Rp) & Jumlah & Satuan & Subtotal (Rp) \\
\hline 1. & F00232 & Wira & Gas LPG $3 \mathrm{~kg}$ & 18,000 & 5 & Tabung & 90,000 \\
\hline 2. & F00232 & Wira & Gas LPG 5,5 & 70,000 & 5 & Tabung & 350,000 \\
\hline 3. & F00233 & Raimah & Gas LPG 5,5 & 70,000 & 10 & Tabung & 700,000 \\
\hline 4. & F00233 & Raimah & Gas LPG 5,5 & 70,000 & 3 & Tabung & 210,000 \\
\hline 5. & F00234 & Rudi & Gas LPG $12 \mathrm{Kg}$ biru & 150,000 & 4 & Tabung & 600,000 \\
\hline 6. & F00234 & Rudi & Gas LPG $3 \mathrm{~kg}$ & 18,000 & 15 & Tabung & 270,000 \\
\hline 7. & F00236 & muni & Gas LPG 5,5 & 70,000 & 5 & Tabung & 350,000 \\
\hline 8. & F00237 & yet & Gas LPG $12 \mathrm{Kg}$ biru & 150,000 & 3 & Tabung & 450,000 \\
\hline 9. & F00237 & yet & Gas LPG $3 \mathrm{~kg}$ & 18,000 & 10 & Tabung & 180,000 \\
\hline \multicolumn{7}{|c|}{ Total } & $3,200,000$ \\
\hline \multicolumn{8}{|c|}{$\begin{array}{l}\text { Agam, 17-03-2019 } \\
\text { Pimpinan }\end{array}$} \\
\hline
\end{tabular}

Gambar 16. Laporan Pelanggan harian

\section{Laporan Data Pemesanan Bulanan}

Untuk dapat melihat laporan data pemesanan admin mengklik menu laporan data pemesanan bulanan. Kemudian admin akan diminta untuk mengtrikan tanggal dan nama pimpinan maka akan tampil laporan data pemesanan Bulanan dapat dilihat pada Gambar 17.

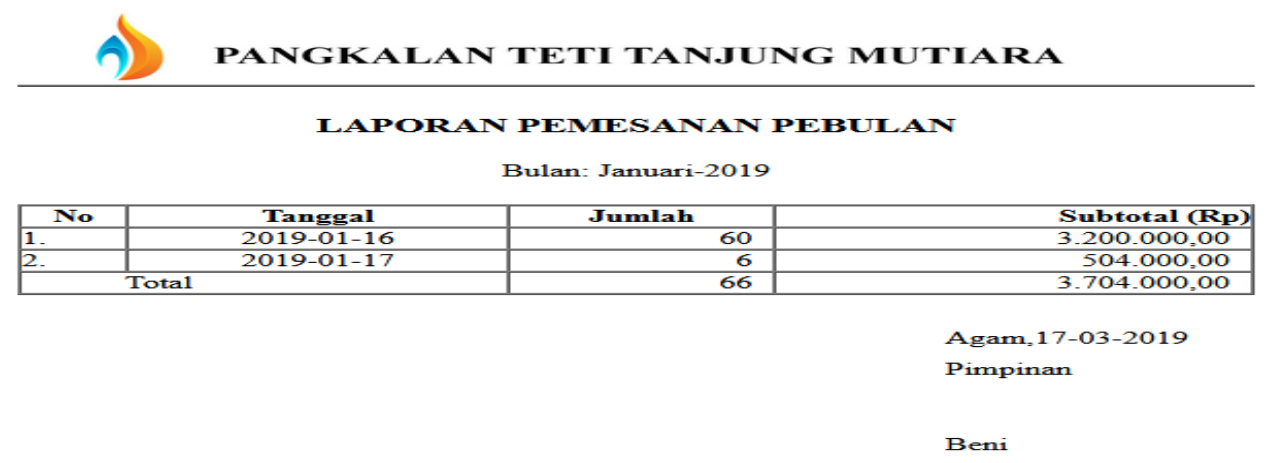

Gambar 17. Laporan Data Pemesanan Bulanan

3. Laporan Data Persediaan Gas

Untuk dapat melihat laporan data pesediaan gas admin mengklik menu laporan data persediaan. Kemudian admin akan diminta untuk mengtrikan tahun dan nama pimpinan maka akan tampil laporan data persediaan dapat dilihat pada Gambar 18.

PANGKALAN TETI TANJUNG MUTIARA

\begin{tabular}{|c|c|c|c|c|c|}
\hline \multicolumn{6}{|c|}{ Laporan Persediaan Gas LPG } \\
\hline \multicolumn{6}{|c|}{ Tanggal :01-02-2019 } \\
\hline No. & Kode Gas & Nama Gas & Satuan & Harga (Rp) & Stock \\
\hline 1. & G00139 & Gas LPG 5,5 & Tabung & 70,000 & 37 \\
\hline 2. & G00140 & Gas LPG $12 \mathrm{Kg}$ biru & Tabung & 150,000 & 43 \\
\hline 3. & G00141 & Gas LPG 3kg & Tabung & 18,000 & 1650 \\
\hline & & & $\begin{array}{l}\text { Agam, } 01 \\
\text { Ttd. }\end{array}$ & & \\
\hline
\end{tabular}

Gambar 18. Laporan Data Persediaan 


\section{KESIMPULAN}

Berdasarkan dari hasil penelitian yang peneliti lakukan di Pangalan Teti Tanjung Mutiara Kab. Agam, maka dapat diambil kesimpulan sebagai berikut :

a. Sistem informasi pemesanan gas LPG berbasis websiste dapat membantu masyarakat melakukan pemesaan secara online dan tanpa harus datang langsung untuk melakukan pembelian gas LPG.

b. Sistem informasi pemesanan gas LPG dapat membantu masyarakat mendapatkan informasi persediaan gas LPG.

c. Sistem inforamsi berbasis website dapat membantu meningkatkan pangsa pasar sehingga dapat meningkatkan pelanggan yang melakukan pemesanan gas LPG pada Pangkalan Teti Tanjung Mutiara.

d. Sistem inforamsi berbasis website dapat meningkatkan jumlah pelanggan pada Pangkalan Teti Tanjung Mutiara

Ucapan Terima Kasih

Berisi ucapan terima kasih kepada lembaga LPPM STMIK Indonesia Padang dan juga kepada Pimpinan Pangkalan Teti Tanjung Mutiara yang telah membantu dalam pelaksanaan penelitian ini.

\section{DAFTAR PUSTAKA}

Agus Umar Hamdani, Rakha Luri Mubarak. 2019. Model E-Commerce Dengan Metode Web Enginering Method Untuk Menunjang Pemasaran Produk Pada XYZ Pet Shop. Prosiding SENDI_U 2019, 978-79.

Andrianal, Ruli, Eka Prasetyaningrum, and S Kom. 2019. Sistem Informasi Pendistribusian Gas Lpg Di PT . Budi Bhakti Kalimantan Berbasis Web. Jurnal Penelitian Dosen Fikom UNDA.

Anggadini, Sri Dewi. 2013, Analisis Sistem Informasi Manajemen Berbasis Komputer Dalam Proses Pengambilan Keputusan. Majalah Ilmiah Unikom, 176-87.

Arman1, Wahyudi2, Desy Erlina3. 2019. Penerapan Sistem Pendukung Keputusan Penentuan Arah Minat Siswa Pada SMA N 14 PADANG Berbasis Web Dengan Metode AHP, UMSB Rang Teknk Journal, 2, 179-86.

Jayanti, Wanty Eka, Eva Meilinda, and Desi Desi. 2018. Perancangan Sistem Informasi Manajemen Distribusi Gas Elpiji Berbasis Web Pada PT. Mita Kalbar Pontianak. Jurnal Khatulistiwa Informatika 6, 2, 151-58.

Kurniawan, Wahyu Joni. 2015. Sistem Informasi Pengelolaan Laboratorium Komputer UPIYPTK Padang. Jurnal Edik Informatika 2 (1): 95-101.

Marlinda, Linda, and Abdul Hamid. 2014. Sistem Informasi Budi Daya Jamur Menggunakan Metode Web Engineering, Seminar Nasional Sains dan Teknologi 2014 (November): 14.

Mubarok, Ade, Himam Dwipratama Suherman, Yudi Ramdhani, and Salman Topiq. 2019. Sistem Pendukung Keputusan Kelayakan Pemberian Kredit Dengan Metode TOPSIS. Jurnal Informatika, BSI, 6 (1): 37-46.

Ramadhani, Nurul Azizah Yaoma. 2011. Pembangunan Sistem Informasi Penerimaan Siswa Baru Di Sekolah Menengah. Journal Speed Sentra Penelitian Engineering dan Edukasi 3 (3): 35-43.

Riswan, M, and A Sahari. 2019. Penentuan Rute Terpendek Pendistribusian Tabung Gas LPG 3 Kg PT . Fega Gas Palu Pratama Mengunakan Algoritma Tabu Search, 16: 221-29. 
Suryadi, Lis. 2012. Pendistribusian Gas Lpj Bersubsidi Dengan Metodologi Object Oriented Studi Kasus PT . Xyz. Seminar Nasional Informatika 2012 (semnas IF 2012) ISSN: 1979-2328 UPN Veteran Yogyakarta, 2012, 44-51.

Wibowo, Aan Tri. 2013. Pembuatan Aplikasi E-Commersce Pusat Oleh-Oleh Khas Pacitan. IJNS - Indonesian Journal on Networking and Security - ISSN: 2302-5700 2: 62-67.

Wira, Dede, Trise Putra, and Rahmi Andriani. 2019. Unified Modelling Language ( UML ) Dalam Perancangan Sistem Informasi Permohonan Pembayaran Restitusi SPPD. Jurnal TEKNOIF 7 (1).

Wulansari1, Tiara Rizki, Woro Isti Rahayu2, and Noviana Riza3. 2019. Aplikasi Pemesanan Bahan Bakar Minyak Melalui Media Whatsapp Menggunakan Algoritma Whatsapp Gateway (Sudi Kasus: PT. Pertamina Patra Niaga). Jurnal Teknik Informatika 2(1): 2736.

\section{(c) (i) (2)}

is licensed under a Creative Commons Attribution International (CC BY-SA 4.0) 